\title{
Arts-Based Instructional Leadership: Crafting a Supervisory Practice That SuPPORTS THE ART OF TEACHING
}

\author{
ZACH KELEHEAR \\ University of South Carolina
}

\begin{abstract}
If teaching at its best is an art (Davis, 2005; Sarason, 1999; Grumet, 1993; Eisner, 1985; Barone, 1983; Greene, 1971; Smith 1971), then instructional leadership of teaching, done best, must also be based in art (Behar-Horenstein, 2004; Klein, 1999; Eisner, 1983 \& 1998a; Blumberg, 1989; Barone, 1998). The author examines possible applications of an arts-based approach to instructional leadership (Blumberg, 1989; Pajak, 2003; Barone, 1998). Building on the research base regarding instructional leadership as art form, the author combines the Feldman Method (Feldman, 1995) of critique, Eisner's (1998) notion of connoisseurship, and Ragans' (2005) articulation of the elements of art and the principles of design to construct a practice that captures both the technical craft of teaching and the aesthetic dimensions evident in artistic pedagogy (Eisner, 1983; Sarason, 1999). Preliminary results of an ongoing implementation study are presented.
\end{abstract}

Kelehear, Z. (2008). Arts-based instructional leadership: Crafting a supervisory practice that supports the art of teaching. International Journal of Education Policy and Leadership 3(1). Retrieved [DATE] from http://www.ijepl.org.

\section{Introduction}

Recent federal mandates, such as the No Child Left Behind Act, have called for having a highly qualified teacher in each classroom. In some ways, however, the emphasis on developing the skills for effective teaching has had the unintended consequence of reducing the teaching act to simplistic and formulaic notions. The research literature on what makes for such a highly qualified teacher, however, does not subscribe exclusively to the idea that effective teaching is prescriptive.

Students learn best from teachers who can be characterized as managing the technical as well as authentic or aesthetic dimensions of learning (Lewis, 2004; Newmann \& Wehlage, 1995; Eisner, 1983). The technical skills might include such aspects as content knowledge, organization of instruction, classroom management, and instructional strategies. When one considers the aesthetic or authentic dimensions of effective teaching, one begins to consider attributes such as interpersonal relationships, reflective practice, nuances, and subtleties of positive interactions among students, teachers, and the subject matter (Eisner, 2002; Newmann \&
Wehlage, 1995; Newmann, Marks, \& Gamoran, 1996). Student achievement is supported when teachers can provide instruction that is both technically sound and aesthetically engaging (Eisner, 1998a; Sarason, 1999; Cawelti, 1999a; Cawelti, 1999b; Cotton, 2000; DarlingHammond, 2000; Good \& Brophy, 1997; Lewis, 2004; Marzano, Pickering, \& Pollock, 2001; NASSP, 1997; Wang, et al., 1993a; Wang, et al., 1993b).

Over the past few years the author's research has focused on imagining instructional leadership as an artistic or aesthetic process coupled with technical observations. The instructional leaders who were the subjects of the research were sometimes school building principals and assistant principals; sometimes they were department chairs, lead teachers, or central office administrators. They were all similar, however, in that they shared a responsibility for observing teachers and offering feedback in either formative or summative evaluations. In working with ... skills, the researcher regularly encountered a certain disappointment with the conclusions of the observations. In the pilot study (i.e., first of three phases) of the larger investigation, the pilot study revealed that the 25 instructional leaders were able to

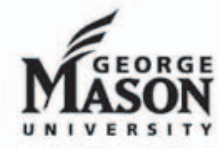


manage with some degree of success the technical dimensions of instructional leadership; that is, they adeptly collected accurate data relative to classroom management and learner outcomes, but their conclusions seemed to miss an important element in many teachers' lessons. That something seemed very important but quite difficult to quantify or easily assess.

Specifically, the study found that focusing exclusively on classroom management and learner outcomes was a sufficient emphasis for some novice teachers or struggling experienced teachers. And the instructional leaders agreed that, consistent with much of what they believed about the instructional leadership of teaching, it was folly to look at other elements of teaching performances if no learning was happening or if the classroom management was not successful. But it was in working with mechanically sound teachers, both novice and experienced, that the participants found instructional leadership that was wholly technical in focus insufficient as a mechanism for informing practice. What they needed was a language and means to capture the aesthetic dimension evident in artistic pedagogy. The language was in art criticism, and the means was in the Feldman Method. The process of sharing, of reflecting, of refining performances in teaching using the language of critique began to create a practice that was more akin to artists who reflect on their work, consider alternative points of view, and try out changes rather than a leadership practice where observing was about inspection and interrogation.

The art of observing, assessing, reflecting, and discussing is a responsibility shared by teacher, student, and instructional leader alike. Davis (2005) states that when students reflect together, when teachers reflect with students, and when leaders reflect with teachers, there is an opportunity to build an environment rooted in inquiry that "fosters and lays bare the stuff of connection and community. Both recognition of difference and mutual respect are necessarily engaged in this process of attending to and seeking to understand other individual's point of view" (p. 15). Arts-based supervisory practice, as witnessed by these 25 participants, was more than a shift in collecting data from teacher observations. Rather, it became a substantial shift in school culture, in how they viewed teachers and their performances, and in how they imagined successful instruction.

This current study, the second phase of a three-part investigation, is an ongoing analysis of instructional leadership as art. The study, first conceptualized in a book titled The Art of Leadership: A Choreography of Human Understanding (2006), led to a pilot study that intro- duced 25 practicing leaders to arts-based instructional leadership. The results of that study revealed that, among other things, the degree to which the instructional leaders became comfortable with both the structure of artsbased observations and the vocabulary required for such analysis directly correlated to their capacity to use artsbased analysis in their schools. Conversely, instructional leaders noted that when leadership, both system level and school building level, did not support alternative assessment strategies, then an arts-based approach simply did not work. This pilot study focused on the training and the structure of arts-based instructional leadership (Kelehear, in press).

The current study extends the pilot study by introducing the results of ongoing training and implementation with regard to the language of arts-based criticism. In terms of language, this study began by specifically examining the applications of the elements of art and principles of design (Ragans, 2005) in helping to describe performances in teaching. Based on the preliminary findings in the pilot study, the study then introduced the leaders to the language for describing and assessing performances in teaching. This manuscript includes the results from the second phase of the training.

The final phase of the three-part investigation involves the leaders implementing a schoolwide staff development program for implementing an arts-based instructional leadership model to be used in peer evaluations, mentoring relationships, and coaching relationships. The arts-based approach is a formative assessment, and the state-adopted assessment instrument is summative. This third phase for implementing an artsbased instructional leadership model is currently underway. Results should be available in 2007-08.

This article continues the story associated with the research on arts-based instructional leadership by (1) providing some theoretical context for the discussion, (2) describing the Feldman Method and its possible application to instructional leadership, and (3) introducing the language of critique as it applies to instructional leadership. It is the author's hope to provide a structure for considering instructional leadership of teaching as art within an arts-based theoretical framework.

\section{A Theoretical Context for Considering Arts- Based Instructional Leadership}

Blumberg (1989) sets the stage for much of this view of instructional leadership as an art form in School Administration as a Craft. Blumberg acknowledges that 
he wanted "to understand and explain [the craft of administration] in the context of the real-life world of the school administrator" and in so doing help the reader develop "the practice of craft" (p. 12) as a sort of habit of mind. For Blumberg, viewing the craft of instructional leadership is only part of developing an enlarged view of life as a craft. This new view of teaching, leading, and learning is for him a significant psychological, emotional, and paradigmatic shift.

Drawing on Blumberg (1989), Pajak (2003), and Barone (1998), this article offers a definition of the somewhat elusive challenge of seeing instructional leadership as art. Barone's (1998) research in some ways casts the longest shadow on this work, because it was he who framed Eisner's $(1982,1983)$ view that if one views teaching as art, then one can begin to see instructional leadership of teaching as art as well. Barone frames the notion of instructional leadership as an aesthetic dimension but notes that there is little consensus that teaching is an art-like activity. Given this reality, questions also remain about the advantages and disadvantages of seeing instructional leadership of teaching as aesthetic.

Conversely, this article suggests that viewing instructional leadership as aesthetic might, in fact, enlarge the view of what effective teaching can become. Additionally, the supervision-as-art metaphor allows one to develop a different view not only of teaching differently but also the instructional leadership of teaching.

If teaching at its best is an art (Davis, 2005; Sarason, 1999; Grumet, 1993; Eisner, 1985; Barone, 1983; Greene, 1971; Smith 1971), then instructional leadership of teaching, done best, must also be based in art (Behar-Horenstein, 2004; Klein, 1999; Eisner, 1998a \& 1983; Barone, 1998; Blumberg, 1989). But to observe teaching as art, one would do well to develop a mechanism for seeing it as an artist might view a painting or a choreographer a dance. One mechanism that may support such a view comes in the form of the Feldman Method and its use of the elements of art and the principles of design.

\section{Observing Performances in Art: Feldman Method Applied to Instructional Leadership}

Through his years of work in art education at the University of Georgia, Feldman (1995) has offered many generations of artists a simple structure for engaging the complicated process of art critique. His method offers four steps to help guide observers or artists through a process of public analysis:
Description: The goal is to describe objectively what you see; the method especially emphasizes that no judgments be made.

Analysis: The goal is to describe what you see and to list your emotional reaction to what you see. How does the observation make you feel? How might it make others feel?

Interpretation: The goal is to find meaning in what you see. Does it work? Why? What do you think the artist is trying to do? What is the goal? What symbolic goals emerge? What do they mean?

Judgment: The goal is to evaluate what you see. How could the artist have been more successful? Do you like it? Why or why not? Is it good? Does it work? Does it function?

Feldman's approach helps one make public what might otherwise remain a private experience. The private experience is one of a connoisseur (Eisner, 1998b). The public expression of the private experience is educational criticism (Eisner, 1998b). In discussing this dichotomy of public and private experience when encountering art, Eisner (1998b) notes: "Connoisseurship, unlike criticism, is a private act. Its aim is to appreciate the qualities that constitute some object, situation, or event. To be a connoisseur in some domain means to notice or experience the significant and often subtle qualities that constitute an act, work, or object and, typically, to be able to relate these to the contextual and antecedent conditions" (p. 85). Later, Eisner states: "For connoisseurship to have a public presence, we must turn to criticism, for criticism provides connoisseurship with a public face" (p. 85). It is through this shift from a private sense or feeling to a public expression that Feldman's Method most directly assisted the 25 school leaders involved in this study. Many were able to observe teachers and have a sense of something going well or not; but for them to express this sense, this feeling, in a public way required both a process and a vocabulary suited to an arts-based description of teaching performance.

The key to encouraging the leaders to apply the Feldman Method to engage in critique and aesthetic evaluations of teaching was to begin using the language of the discipline that is rooted in critique and aesthetics, that is to say, art. (Klein, 1999; Behar-Horenstein, 2004). Working together, the participants took the four steps for art critique and applied them to teacher observation. The goal was to offer a process through which the instructional leaders might begin observing teaching in much 


\begin{tabular}{|c|c|}
\hline Steps in Analysis & Prompting Questions \\
\hline Description & $\begin{array}{l}\text { 1. How might one describe the lesson I am planning? } \\
\text { 2. What is the size of the class? } \\
\text { 3. What ages are the children? How many boys and girls? } \\
\text { 4. What are the learning outcomes? } \\
\text { 5. How does the classroom management support the attainment of the learning outcomes? } \\
\text { 6. Any other technical considerations? }\end{array}$ \\
\hline Analysis & $\begin{array}{l}\text { 1. What is the instructional strategy? } \\
\text { 2. How does the instructional strategy align with the learning outcomes? } \\
\text { 3. In what ways might the instructional strategy affect classroom management? } \\
\text { 4. What type of classroom management will be useful to support the instructional strategy } \\
\text { and the learning outcomes? }\end{array}$ \\
\hline Interpretation & $\begin{array}{l}\text { 1. In what ways does my instructional strategy support my view of teaching and learning? } \\
\text { 2. How might the organization of the lesson communicate value to the students? } \\
\text { 3. How does my assignment communicate my assumptions about student maturity? } \\
\text { 4. In what ways did I make the content authentic relative to student interests? } \\
\text { 5. How might the lesson elicit feelings or emotions among students? } \\
\text { 6. How did the lesson make me feel as an instructor? } \\
\text { 7. In what ways might the lesson affect students' perception of schooling and learning? } \\
\text { 8. What did I learn in conducting this lesson that will compel me to adjust my pedagogy? } \\
\text { 9. Do my students see me as authentic? } \\
\text { 10. In what ways do I communicate authenticity to my students? }\end{array}$ \\
\hline Judgement & $\begin{array}{l}\text { 1. Were the learning outcomes achieved? How do I know? What is the evidence? } \\
\text { 2. How did the classroom management support the attainment of the learning outcomes? } \\
\text { 3. How might the lesson have been improved? } \\
\text { 4. Reflecting on the lesson, what specific items would I change to improve the lesson? } \\
\text { 5. How might students be different, emotionally or intellectually, before the class as com- } \\
\text { pared to after the class? } \\
\text { 6. In what ways did I encourage students to reflect and make meaning out of experience? } \\
\text { 8. In what ways did I model reflection that leads to new understanding? } \\
\text { 8. Did the students view the lesson as a positive experience or a negative one? }\end{array}$ \\
\hline
\end{tabular}

the same way Feldman encourages observers to view art. The supervisors of instruction, using the Feldman framework, constructed the questions in Table 1(this page) to help teachers reflect on their lesson plans and to guide pre- and post-observation conferences.

An early attempt by one of the instructional leaders to apply the Feldman model to a classroom observation yielded the following description.

Description: The history class met at 10:23. There were 20 students in the class. The room was set up in groups of four desks. As students entered, they began work on a "Thought of the
Day" found on the board. The classroom had four maps on the walls. Student projects were found on one of the walls.

Analysis: I felt comfortable with the lesson as students seemed at ease with the teacher's routine. I sensed that the students felt welcome in the classroom and that it was a safe place for them to experiment with ideas. I also found some satisfaction in the fact that the learning time seemed valued by the students and teacher, and the students did not waste their opportunity to learn. 
Interpretation: The teacher communicated a sense of order and focus by having student seating pre-arranged and by having a process for organizing thinking at the first of the lesson. The "Thought for the Day" worked well in that it helped students get to work early in the lesson.

Judgment: The teacher was highly effective in communicating a sense of order, routine and focus. Special emphasis on the elements of line and shape seemed to really pay off in supporting expectations. The teacher and observer had committed to the principle of rhythm for the school year. Clearly, the use of line and shape helped develop a sense of rhythm in the classroom, where learning and individuals were both valued.

In the pilot study, the 25 leaders spent 13 weeks learning to manage and develop this arts-based methodology. Only four of the leaders moved to a level of comfort with this innovation at which they were willing to collaborate to make improvements in it. Twelve others reached a comfort level at which they began considering the consequence this approach might have on teachers and students. The remaining nine leaders really struggled to implement the arts-based approach

But using the Feldman Method to assist arts-based instructional leaders to become both connoisseurs of teaching performance and professionals engaged in educational criticism was only part of the challenge. The next step in the process of promoting an arts-based practice was to provide leaders with a language that might capture the aesthetic and authentic nature of classroom experiences that became art. The elements of art and principles of design would offer a language, a vocabulary, for discussing the art and craft of effective teaching.

\section{Discussing What We See: A Language of Critique}

Rooted in arts-based research (Davis, 2005; Eisner, 2002, 1998a, 1998b), the elements of art and the principles of design (Ragans, 2005) provided an arts-based supervisory practice (Barone, 1998; Blumberg, 1989; Eisner, 1982, 1983; Pajak, 2003) for describing, analyzing, interpreting, and evaluating performances in teaching. Borrowing from the art criticism paradigm offered by Ragans, the elements of art were line, value, shape, form, space, color, and texture. The principles of design were emphasis, rhythm, movement, balance, proportion, variety, and harmony/unity.
The elements provided a language for describing the specific, observable, measurable attributes of the classroom experience. They were more specific and concrete in nature than the broadly framed principles of design. In fact, the 25 instructional leaders gave more attention to the elements when working with teachers who were new to the profession, new to the district, new to a grade level, and new in other ways. Because of the many demands and pressures on them, these teachers tended to work at lower levels of conceptualization and required close instructional leadership and guidance.

On the other hand, the principles of design were thematic, broad, and organizing concepts that communicated ways in which teachers and school leaders chose to manage the elements across individual classrooms and across disciplines. Teachers and leaders who were working at higher levels of conceptualization could more readily understand and manage the principles of design as applied to teaching performances.

Nevertheless, both the elements and principles could conceivably be viewed either in concrete or abstract terms, as craft or aesthetics. The key difference was in the scope of the observation. The elements tended to focus on individual classrooms. The principles tended to focus on multiple classrooms or schoolwide initiatives. Within the Feldman Method, the elements and principles were most thoroughly discussed in the analysis stage. Other components of the Feldman Method were similar, whether the discussion was about specific classrooms or about systemwide innovations.

In conversations between supervisors and teachers, areas of investigation and topics ranged from the technical to the aesthetic areas. By the very nature of the types of questions asked in each category, participants in the study began to get a sense of how the art of instructional leadership was being characterized as both technical and aesthetic. The fundamental belief of instructional leadership as art, however, was grounded in the qualitatively different conversations that occurred between teachers and supervisors. The conversation moved away from instructional leadership as strictly technical and concrete (i.e., describe and analyze) and toward instructional leadership as aesthetic and abstract (i.e., interpret and judge). Table 2 (page 6) depicts this profound change from the specific to the abstract.

It was in the second of the four steps (analysis) that the 25 participants in this study became highly dependent on arts-based vocabulary to discuss observations as critique. In other words, in observing teaching and 


\begin{tabular}{|c|l|}
\hline \multicolumn{2}{|c|}{ Table 2: Typical Expressions of Instructional Leaders Using Art Conversation } \\
\hline $\begin{array}{c}\text { Level of Criticism } \\
\text { (Craft or Technical) }\end{array}$ & Objectively, what do I see? Withhold evaluation of the lesson or teacher. \\
\hline $\begin{array}{c}\text { 2. Analysis } \\
\text { (Craft or Technical) }\end{array}$ & $\begin{array}{l}\text { Were the learning outcomes met? How did classroom management affect the attain- } \\
\text { ment of the learner outcomes? }\end{array}$ \\
& $\begin{array}{l}\text { For individual classroom observations: What elements were evident in the lesson? } \\
\text { What element might have been included to make the lesson more effective? } \\
\text { For schoolwide or interdisciplinary units: What principles were evident? What prin- } \\
\text { ciples need to be addressed to support student and teacher learning? }\end{array}$ \\
\hline $\begin{array}{c}\text { 3. Interpretation } \\
\text { (Art or Aesthetic) }\end{array}$ & $\begin{array}{l}\text { How did the methodology affect students? How did the methodology interface with } \\
\text { the subject matter? How did the lesson match or mismatch the learner needs and } \\
\text { styles? How did you feel in the observation? How did the teacher(s) seem to feel? } \\
\text { How did the students seem to feel? How do you know? }\end{array}$ \\
\hline $\begin{array}{c}\text { 4. Judgment } \\
\text { (Art or Aesthetic) }\end{array}$ & $\begin{array}{l}\text { Was the lesson successful? In what ways might it have been improved? What recom- } \\
\text { mendations might be useful to improve the next lesson? What type of action plan } \\
\text { might be useful in supporting the continued improvement? }\end{array}$ \\
\hline
\end{tabular}

schooling as artistic endeavors, the leaders began to move from the notion of connoisseur to the notion of being engaged in educational criticism. In that shift, they required a language that was arts-based and enabled them to capture and describe performances in teaching. The following section contains examples of how the participants examined individual classrooms (i.e., elements) and schoolwide innovations (i.e., principles). In both categories, the elements of art and the principles of design are defined and then accompanied by prompting questions. This structure provided significant support for the leaders as they struggled to describe what they saw. As S. R., an elementary school assistant principal, stated, "I simply had to use the questions exactly as they were in the list. Next time I might add some questions. But not this time."

\section{Elements of Art for Instructional Leadership: Describing Individual Teacher Performances}

\section{Line}

- Expectations: What are the limits and boundaries of the supervisor's role in the teacher's classroom? What might the teacher and supervisor expect from this relationship? How do students know their role in the learning process?
Value

- Priority: How might the supervisor help the teacher reflect on what is pressing, what is immediate, and what is important in a given lesson? How might supervisory practice communicate the relationship between what the teacher says is important, what the teacher believes is important, and what the teacher actually practices?

\section{Shape}

- Details: In what ways might the supervisor help the teacher see all the non instructional challenges that affect instructional effectiveness? How can supervisory practice help teachers with the necessary, albeit non instructional, tasks that come with teaching?

\section{Form}

- Empathy: In what ways might the supervisor discern what the teacher is saying, not saying, or meaning to say? How can the supervisor help the teacher view instruction from the students' perspectives? How can the teacher begin to see instruction from the supervisor's perspective?

\section{Space}

- Growth: What can a teacher manage? What is too much? How can supervisory practice provide a bal- 
ance between support and challenge? How does this balance create opportunities for growth?

\section{Color}

- Diversity: How can instructional leadership support standards for instruction but also embrace diverse teaching styles?

\section{Texture}

- Bridges: How can leaders bring staff together in meaningful partnerships? How can instructional leadership connect teachers in like subject areas within the school? How might instructional leadership help connect teachers and subjects across subject areas?

\section{Principles of Design for Instructional Leadership: Describing Interdisciplinary or Schoolwide Performances in Teaching}

\section{Emphasis}

- Focus: Given the diversity of teaching styles, what will be the schoolwide focus for improving instruction? What will be common themes across subject areas and grade levels?

\section{Rhythm}

- Heartbeat: In what ways can instructional leadership help a teacher to identify and support the creative elements in a lesson that bring it to life? In what ways might instructional leadership support a schoolwide initiative to bring vitality and relevancy to instruction?

\section{Movement}

- Development: In what ways is instruction growing in sophistication? In variability? How can instructional leadership communicate to the larger staff the developmental growth of instructional practice across programs?

\section{Balance}

- Bidirectionality: In what ways is instructional leadership supporting teacher growth and also supervisory professional growth? Is instructional leadership kindling the professional fire across programs? Is instructional leadership coming to know all teachers so that support can be offered professionally and personally?

\section{Proportion}

- Prescription: In what ways are the teacher's choices an appropriate plan for the needs and abilities of the students? In what ways are the supervisor's choices appropriate for the needs and abilities of teachers? How might supervisory practice help mentor the organization?

\section{Variety}

- Creativity: While demanding standards, how can instructional leadership also support individual creativity and not standardization of practice? What common themes bind the staff amid individual freedoms? In what ways does instructional leadership celebrate instructional creativity?

\section{Harmony/Unity}

- Connections: In what ways can teachers remain in touch with what children need when so many external matters confront them? In what ways might instructional leadership support diverse instructional practices for the synergistic benefit?

\section{Putting the Elements and Principles to Work with the Feldman Method}

Through Feldman's four-step process and the accompanying language of describing art (Ragans, 2005), the instructional leaders were compelled to resist making quick judgments or evaluations of performances in teaching. To introduce the leaders to the Feldman Method and the elements of art and principles of design, a second class session was convened at the Columbia Museum of Art. The leaders were asked to apply the Feldman Method to two pieces at the museum. In that exercise, they were challenged to describe each piece using the elements and principles.

As anticipated, the leaders had some success with the elements of art. Because they are formal qualities-in other words, more concrete and specific - the elements made sense to the leaders. The principles of design, however, remained more elusive in the early observations. Just as when the leaders observed teaching performance with a checklist and thus looked for specific behaviors, they could look at a work of art for the specific attributes of the formal properties. When discussion began about the principles of design evident in the selected works, however, there seemed to be more silence than conversation. It clearly took more time to begin becoming comfortable with the principles of design as a part of describing art. This reality helped the researcher anticipate struggles when applying the art metaphor to instructional leadership.

The anticipated struggles of moving from the elements to the principles were realized toward the middle 
of the leadership training (after week 6 of 13), when the leaders began considering the guiding, or thematic components of effective instruction. As they tried to identify the cohesive powers that kept the elements together in a unified whole, the leaders struggled to capture the abstract influences that most frequently characterize principles of design.

At the end of the 13-week training session, the leaders completed a questionnaire in which they were asked to reflect on their comfort with notions of elements of art and principles of design and their possible application to instructional leadership. Of the 25 leaders, only four had any degree of comfort with a principle of design. By comparison, among the other 21, who listed elements of art as something with which they were comfortable, five also listed multiple elements with which they were comfortable when conducting observations. One leader, who had acknowledged a considerable bit of comfort with all the elements and many of the principles, was clearly ahead of the others in developing an arts-based approach to supervision. In discussing an element and a principle, K. B., a principal at a rural district noted:

An element useful for an instructional leader is value. Following is a sample staff development plan for the introduction and development of value. Value is defined as priority, that is, what is considered most important. Therefore, the first step in the staff development process would be the development of a survey to determine what the faculty "values" most. Depending on the results of the survey, a specific staff development program could be designed. However, for the sake of this example, let's assume that improving academic performance is found to be what the faculty values most.

The principle of movement holds the most promise for me both professionally and personally. Movement could be equated with the concept of progress. I hope to progress professionally as I desire to grow in many ways. For example, I would like to learn more about the scheduling process. I do not want to appear "busy" in that I am not accomplishing specific goals. Rather, I desire to set goals and work toward them by exposing myself to new and challenging situations.

By her example, and the many others she offered, it was clear that this leader was struggling to extend her reach in leadership influence and the arts-based approach was helpful to her. In a surprise finding, the four leaders who were able to manage principles of design pulled together several teachers and asked them to agree on a single principle that they all believed reflected a shared vision for teaching and learning. Thereafter, these leaders observed individual teacher classrooms with the elements providing the language for using the Feldman Method; brought the teachers together and had them share reflections on the lessons; and, finally, led discussions of how a shared principle revealed itself in the different classrooms in the different lessons. It was that principle-and the leaders really had a gestalt moment here-that provided a language for describing, analyzing, interpreting, and judging the school's performance across classrooms.

Each week the leaders came together to discuss the feelings, reactions, and descriptions that emerged from their observations. In the classroom observations the participants conducted over the following weeks, the elements of art and the principles of design helped guide the conversation toward engagement and meaning-making and away from quick judgments or opinions-just as had happened in the museum experience. The elements and principles were not the focus, ultimately, but they did provide the vehicle for a journey into the deeper meaning of classroom performance. As different observers encountered the art of teaching, the elements and principles provided a common process and mechanism for discussion. The beauty of bringing the elements and principles into balance with the Feldman Method was the fact that there was some sense of standards of evaluation and assessment without predicting or prescribing (i.e., standardizing) the final or ultimate judgment.

Instructional leadership clearly needs standards for practice so that different observers at different times in different places have common language to make comparisons. In this study, the elements of art for instructional leadership and the principles of design for instructional leadership provided the starting point for both intrapersonal reflection and interpersonal conversations. Their use gave the teacher and instructional leader points of departure as both parties tried to describe and analyze what had happened in the classroom. Only after those discussions did the instructor and observer begin to engage in interpretation and judgment. Interviews with both teachers and principals revealed in quick order that instructional leadership had frequently been a quick, drop-in visit and an equally quick judgment about teaching performance. What highly qualified teachers and supervisors did differently in this arts-based approach was to engage in conversation that qualitatively and 
quantitatively became different from the traditional checklist of teacher behaviors found in many assessment instruments today.

Another way to conceptualize this dual responsibility of both parties was that during the process of instructional leadership of teaching, the person observed and the supervisor engaged in a personal and private reflection on experience and then came together to describe, analyze, interpret, and judge the observation through reflective, supportive, and public conversations. As Davis (2005) puts it, "In the process of creating, artists reflect on their work, consider alternative points of view, try out changes, and begin the cycle of revision again" (p. 11). This interaction was the model and process that art offered arts-based instructional leadership.

Just as an artist and an observer of artwork have a shared responsibility for making meaning or making sense out of the experience, the supervisor and teacher also shared in the responsibility for making informed decisions about what was working and what was not.

\section{Emerging Realities in Phase II of the Study}

The language of art used in this study included seven elements of art and seven principles of design. In each school setting, and in each classroom, these 14 attributes assumed relative positions of importance. For example, in one school the leadership element of texture played a more prominent role, whereas at another school shape or form dominated. Although one element may have been most apparent, all other elements were often still present, albeit in a decreased stature.

By using the language that the elements provided and coupling it with the organizing nature of principles, the leaders began to grapple with the different images of instructional leadership. What was significant about their use, however, was that they all extended the nature of the conversation in supervisory practice. As T. B., a middle school principal, commented, "At first I was frustrated with the time this all took. I wanted to do the fiveminute walk-through, enter yes or no on my hand-held computer, and then move on to the next classroom. The district was keeping count of my number of visits. But after a while I began enjoying taking time to visit with the new teachers. Writing the narrative helped me tell more about what was really happening. I think the teachers appreciated the time, too."

Historically, instructional leadership has been a process of oversight, investigation, and inspection (Glanz, 1998). Put into the language of art, instructional leadership has copious experience as critique of technical skills, the public articulation of what is right and wrong with teaching performance. What has been missing, however, is instructional leadership that sees instruction more broadly-as aesthetics-and encourages private, interpersonal conversations. When the instructional leaders engaged in both critique and aesthetics, the observation data became more real or authentic and more about process and creation than static product. Arts-based instructional leadership became a habit of mind rather than a collection of replicable habits and checklists for the participants in this study.

Interestingly, in the early stages of the implementation of the study, the group described instructional leadership as an "either/or" challenge. They saw observation as either a technical (i.e., elements) or an aesthetic (i.e., principles) experience. They did not see the process as a continuum. By the sixth week of implementation, however, they began to encourage teachers to reflect privately on their own experiences in the classroom and also to discuss publicly with peers and supervisors. Instead of "either/or," the process became "first, then next." The elements of art and the principles of design used in supervisory practice encouraged both the private and public conversations about the nature of teaching. As a result, instructional leadership of teaching began to emulate Davis' (2005) model - a process by which teachers create, reflect, consider, change, and begin again.

The application of the elements of art and principles of design toward an understanding of the nature of instructional leadership seemed both a logical and natural progression. However, the relationship had not been fully established or adequately articulated. One cannot presume to fill in all the blanks with this study but the study does extend the conversation of how instructional leadership might indeed be art. There is much more to be done in this area.

\section{Conclusions on the Conceptual Basis for Instructional Leadership as Art}

Considering an arts-based approach to instructional leadership has certainly affected the school leaders in a variety of ways. V. C., an elementary school principal, put it this way in her journal:

I have been challenged to step outside of my analytical comfort zone and become more global and abstract in my analysis of leadership. Furthermore, by understanding these seven elements, an educator can analyze his/her school 
building to ensure that all of them exist in some aspect. Notably, as we begin new construction projects in our school district, I can offer insight into the planning and design of these facilities, but I will also be able to offer tips to include these elements in the hallways, classrooms, front office lobby, cafeteria, etc., so that the culture and vision of the school is readily evident.

In trying to reconcile the emphasis on scientifically based approaches with more humane approaches to supervision, K. G., principal of a large urban high school, drew this conclusion:

Supervision as an art involves the supervisor's continuous development of his/her own skills so that there is full understanding and appreciation of teachers' skills. It also involves having an appreciation for teachers' styles. It is suggested that this is best accomplished through being in touch with your own style of teaching. Further, it is effective communication with the teacher relative to their instruction and the ability to see and appreciate the emotion, rhythm, and art in the observed instruction. It requires being able to discern the finest of details, just like analyzing a work of art. The more perceptive, observant, and intuitive the supervisor, the greater the potential for that individual to provide for the specific needs of the employees. This results in greater employee effectiveness.

Supervision as a scientific endeavor requires much less cognitive energy. This involves collection of performance data and intervention strategies for improvement. This process seeks to utilize data in planning and to gauge progress and process. Outcome data are greatly emphasized. The human element is not factored into evaluating performance. It is a focus on stated objectives and what the data indicate relative to those objectives.

These participants' assertions are enlightening. In fact, across the range of all participants' reactions, one truth consistently emerged: An arts-based approach provided these instructional leaders with a way to really capture what was most important in teaching performances. S. R., an elementary school principal in a rural district, insightfully stated:

I agree that leadership and supervision is "about relationships." I also agree that leadership becomes art when "we value the qualitative nature of relationships and learn to choreograph human understanding." We can empower or shatter the confidence and resilience of the teachers we supervise through the quality of our relationships and the nature of our communication. We, as supervisors, must take responsibility for building the necessary rapport which creates the environment for the professional growth of others. By providing a common lexicon, using the elements of art and the principles of design as our vocabulary, we are empowered as educational leaders to choreograph understanding and communication, thereby improving our ability to effectively coach the teachers of our children.

Observations in elementary schools where principals include art and support art instruction revealed students' belief in their own capacity to do art. As first grader Ben remarked, "Okay, enough of the talking. Let us make our stuff." Observations in high schools found art students quietly engaged in the process of making their product. What they were doing mattered very much to them, "not like the other stuff we have to do at school," as one student commented. But the number of students engaged in art diminishes between elementary school and high school. Somewhere along the journey from kindergarten to high school, the capacity for students to see life as an aesthetic experience seems to be getting lost. Part of the students' numbness that comes with years may be the product of assessment-driven teaching that becomes all about technical skills and little about real-life interactions forcing more and more meaningless information on students (Glasser, 1975; Starratt, 2004). It is not the teachers' fault, entirely, for they are not often expected to do more than show results on tests. Rather, the fault lies with stakeholders, policymakers, boards of education, school instructional leadership, professors of instructional leadership, and parents because they acquiesce to the notion that good test results, under the code of scientifically based teaching practices, are the goal at the exclusion of all else. Recognizing that good teaching is indeed art, and that artful instructional leadership acknowledges this reality, teachers and supervisors can begin helping students learn less about what is on the tests and more about life's aesthetic qualities that help them understand themselves, others, and their world. In one way of thinking, instructional leadership as art recognizes, as Steinbeck (1955) noted, that "a great teacher is a great artist" and that "there are as few as there are any other great artists" (p. 7). The process of seeing instructional leadership of teaching through the elements of art and 
the principles of design will help both supervisors and teachers begin to recognize and support teaching as an art form.

If we fail to prepare supervisors of instruction with the tools, mechanisms, perspectives, and intellect for an enlarged understanding of teaching, then we risk losing the very best teachers, who yearn for a vocation that embraces their courage to do things differently. And when we continue to do instructional leadership solely as inspection, data collection, and checklists, then we risk deflating the soul of those teachers who see instruction as art and their curriculum as the canvas upon which students wholly engage in the full aesthetic of learning and of life.

\section{References}

Barone, T. E. (1983). Things of use and things of beauty: The story of the Swain County High School arts program. Daedalus, 112(3), 1-28.

Barone, T. E. (1998). Aesthetic dimensions of instructional leadership. In G. R. Firth \& E. F. Pajak (Eds.), Handbook of research on school instructional leadership (pp. 1104-1122). New York: Simon \& Schuster Macmillan.

Behar-Horenstein, L. S., Mitchell, G. S., \& Dolan, T. A. (2004, April). A multidimensional model for analyzing educational processes. International Journal of Leadership in Education, 7(2), 165-180.

Blumberg, A. (1989). School administration as a craft: Foundations of practice. Boston: Allyn \& Bacon.

Cawelti, G. (Ed.). (1999a). Handbook of research on improving student achievement (2nd ed.). Arlington, VA: Educational Research Service.

Cawelti, G. (Ed.). (1999b). Portraits of six benchmarks schools: Diverse approaches to improving student achievement. Arlington, VA: Educational Research Service.

Cotton, K. (2000). The schooling practices that matter most. Portland, OR: Northwest Regional Educational Laboratory, and Alexandria, VA: ASCD.

Crawford, D. (1987, Summer). Aesthetics in disciplined-based art education. Journal of Aesthetic Education, 21(2), 227-239.

Darling-Hammond, L. (2000). Teacher quality and student achievement: A review of state policy evidence. Education Policy Ansalysis Archives, 8(1). Retrieved November 18, 2007, from http://epaa.asu.edu/epaa/v8nl/
Davis, J. H. (2005, September). Redefining Ratso Rizzo: Learning from the arts about process and reflection. Phi Delta Kappan, 87(1), 11-17.

Eisner, E. W. (1982). An artistic approach to supervision. In T. J. Sergiovanni (Ed.), Supervision of teaching, 1982 Yearbook (pp. 5-52). Alexandria, VA: ASCD.

Eisner, E. W. (1983, January). The art and craft of teaching. Educational Leadership, 40(4), 4-13.

Eisner, E. W. (1985). The educational imagination: On the design and evaluation of school programs (2nd ed.). New York: Macmillan.

Eisner, E. W. (1998a). The kind of schools we need. Portsmouth, NH.: Heinemann.

Eisner, E. W. (1998b). The enlightened eye: Qualitative inquiry and the enhancement of educational practice. Upper Saddle River, NJ: Prentice-Hall.

Eisner, E. W. (2002). The arts and the creation of mind. New Haven, CT: Yale University Press.

Feldman, E. B. (1995). Philosophy of art education. Upper Saddle River, NJ: Prentice all.

Glanz, J. (1998). Histories, antecedents, and legacies in school supervision. In G. R. Firth \& E. F. Pajak (Eds.), Handbook of research on school supervision (pp. 39-79). New York: Simon \& Schuster Macmillan.

Glanz, J. (2002). Finding your leadership style: A guide for educators. Alexandria, VA: ASCD.

Glasser, W. (1975). Schools without failure. New York: Harper \& Row.

Glickman, C. D. (2002). Leadership for learning: How to help teachers succeed. Alexandria, VA: ASCD.

Good, T. L., \& Brophy, J. E. (1997). Looking in classrooms (7th ed.). New York: Addison-Wesley.

Greene, M. (1971). Art, technique, and the indifferent gods. In R. Smith (Ed.), Aesthetics and problems in education. Urbana, IL: University of Illinois Press.

Grumet, M. R. (1993). The play of meanings in the art of teaching. Theory into Practice, 32(4), 204-209.

Kelehear, Z. (in press). Instructional leadership, connoisseurship, \& critique: Using an arts-based approach to extend conversations about teaching. International Journal of Leadership in Education.

Kelehear, Z. (2006). The art of leadership: A choreography of human understanding. Lanham, MD: Rowman \& Littlefield Education.

Klein, S. R. (1999, January). Creating artful leadership. International Journal of Leadership in Education, 2(1), 23-30. 
Lewis, A. C. (2004, March). Schools that engage children. Phi Delta Kappan, 85(7), 483-484.

Marzano, R. J., Pickering, D., \& Pollock, J. E. (2001). Classroom instruction that works. Alexandria, VA: ASCD.

Moore, R. (Ed.). (1994). Aesthetics for young people. Reston, VA: National Art Education Association.

National Association of Secondary School Principals (NASSP). (1997). Students say: What makes a good teacher? Schools in the Middle, 6(5), 15-17.

Newmann, F. M., \& Wehlage, G. G. (1995). Successful school restructuring. Alexandria, VA: ASCD.

Newmann, F. M., Marks, H. M., \& Gamoran, A. (1996). Authentic pedagogy and student performance. American Journal of Education, 104(4), 280-312.

Pajak, E. (2003). Honoring diverse teaching styles: A guide for supervisors. Alexandria, VA: ASCD.

Ragans, R. (2005). Art talk (5th ed.). Boston: Glencoe / McGraw-Hill.

Sarason, S. B. (1999). Teaching as performing art. New York: Teachers College Press.

Smith, R. (1971). Is teaching an art? In R. Smith (Ed.), Aesthetics and problems of education. Urbana, IL: University of Illinois Press.

Starratt, R. J. (2004). Ethical leadership. San Francisco: Jossey-Bass.

Steinbeck, J. (1955, November) Like captured fireflies. California Teachers Association Journal, 51(8), 7.

Wang, M., Haertel, G. D., \& Walberg, H. (1993a). Toward a knowledge base for school learning. Review of Educational Research, 63(3), 249-294.

Wang, M., Haertel, G. D., \& Walberg, H. (1993b). What helps students learn? Educational Leadership, 51(4), 74-79.

IJEPL is a joint publication of the Association for Supervision and Curriculum Development, the Faculty of Education at Simon Fraser University, and the College of Education and Human Development at George Mason University. By virtue of their appearance in this open access journal, articles are free to use, with proper attribution, in educational and other non-commercial settings 90 days after initial publication. Copyright for articles published in IJEPL is retained by the authors. More information is available on the IJEPL Web site: http://www.ijepl.org 